\title{
Relationship of cutaneous moisture, sebum and pH changes of healthy skin with menstrual cycle
}

\author{
Sağlıklı derinin nem, sebum ve pH değișikliklerinin menstrüel siklus ile ilișkisi
}

๑ Nilgün Küçükaydoğan, ๑ Ekin Șavk*, ๑ Meltem Uslu*, ๑ Neslihan Șendur*,
๑ Göksun Karaman*, ๑ Serkan Demirkan**

Afyon State Hospital, Clinic of Dermatology, Afyon, Turkey

*Adnan Menderes University Faculty of Medicine, Department of Dermatology, Aydın Turkey

**izmir Atatürk Training and Research Hospital, Clinic of Dermatology, Izmir, Turkey

\begin{abstract}
Background and Design: Studies to investigate the change of skin moisture, sebum and pH properties in various physiological processes such as age, gender, pregnancy and menopause are limited. Menstrual cyle is a physiological process that causes changes in various organs and systems in the female body. In this study, possible changes in the moisture, sebum and PH values of the skin with menstrual cycle will be investigated. Thus, it is aimed to determine whether the hormonal changes that drive the menstrual cycle have observable effects on the skin. Materials and Methods: In our study, the relationship of skin moisture, sebum and pH values of healthy skin with the menstrual cycle was investigated with the MPA-5 device. Fifty-one volunteer women aged 21-45, working at the faculty of medicine, and having regular periods were included the study. The measurement was done with MPA-5 device. In this study, the skin PH, humidity and sebum values of the participants were measured 6 times in total during two consecutive menstrual cycles, at the beginning of each cycle (early follicular phase), middle (late follicular phase) and end (midluteal phase). Humidity and PH were measured from 5 different points on the face (glabella, bilateral zygomatic protrusions on both cheeks, mentum on the chin and nose) and sebum was measured from the glabella as a single measurement. Results: When the data obtained from the measurements were evaluated, there were no statistically significant differences in the moisture, sebum and PH values of the skin in accordance with the early follicular phase, late follicular phase and midluteal phase of the menstrual cycle. In addition, age, body mass index and smoking were compared with average sebum, moisture and pH values, and no statistically significant relationship was found.

Conclusion: The fact that hormonal changes in the menstrual cycle do not cause any changes in the moisture, sebum and $\mathrm{pH}$ values of the skin shows that it will not change the outcome of the period of menstrual cycle in the examination of patients, offering daily care products to patients and determining dermatopathological conditions. Clearer results can be obtained by conducting more detailed and long-term studies. Keywords: Skin, sebum, moisture, $\mathrm{pH}$
\end{abstract}

Öz

Amaç: Derinin nem, sebum, pH özelliklerinin yaş, cinsiyet, gebelik ve menopoz gibi çeşitli fizyolojik süreçler ile değişimini araştırmaya yönelik çalışmalar sınırlı sayıdadır. Menstrüel siklus kadın vücudunda çeşitli organ ve sistemlerde değişikliklere neden olan fizyolojik bir proçestir. Bu çalışmada menstrüel siklus ile derinin nem, sebum ve pH değerlerindeki olası değişiklikler araştırlacaktır. Böylece, menstrüel siklusu yönlendiren hormonal değişikliklerin deride gözlemlenebilir etkilerinin olup olmadığının anlaşılması hedeflenmiştir.

Gereç ve Yöntem: Çalışmamızda sağlıklı derinin nem, sebum ve pH değerlerinin menstrüel siklus ile ilişkisi, MPA-5 cihazı ile araştırımıştır. Çalışmaya tıp fakültesi hastanesinde çalışan 21-45 yaş arasında, düzenli adet gören gönüllü 51 kadın olgu alındı. Ölçüm MPA-5 cihazı ile yapıldı. Bu çalışmada katılımcıların yüz derisi pH, nem ve sebum değerleri ardışık 2 menstrüel siklus boyunca, her siklusun başında (erken folliküler fazda), ortasında (geç folliküler fazda) ve sonunda (midluteal fazda) olmak üzere toplamda 6 kez ölçülmüştür. Nem ve pH için, yüz üzerinde

Address for Correspondence/Yazıșma Adresi: Serkan Demirkan MD, İzmir Atatürk Training and Research Hospital, Clinic of Dermatology, İmir, Turkey Phone: +90 55377171 E-mail: serkan.demirkan@yahoo.com.tr Received/Geliș Tarihi: 25.04.2019 Accepted/Kabul Tarihi: 21.04.2020 ORCID: orcid.org/0000-0002-3960-3891

CCopyright 2020 by Turkish Society of Dermatology and Venereology

Turkderm - Turkish Archives of Dermatology and Venereology published by Galenos Yayınevi. 
belirlenen 5 farklı noktadan (glabella, her iki yanak zigomatik çıkıntılar, çenede mentum üzerinden ve burundan olmak üzere), sebum ölçümü ise glabelladan tek ölçüm olarak yapılmıştır.

Bulgular: Yapılan ölçümlerden elde edilen veriler değerlendirildiğinde derinin nem, sebum ve pH değerlerinin menstrüel siklusun erken folliküler faz, geç folliküler faz ve midluteal faz ile uyumlu ölçümlerinde istatistiksel olarak anlamlı farklılık bulunmamıştır. Ayrıca kişilerin yaşları, vücut kitle indeksleri ve sigara kullanımı ile ortalama sebum, nem ve pH değerleri karşılaştııımış, istatistiksel olarak anlamlı bir ilişki saptanmamıştır.

Sonuç: Menstrüel siklustaki hormonal değişikliklerin, derinin nem, sebum ve pH değerlerinde herhangi bir değişikliğe neden olmaması, kişilerin muayenesinde, kişilere günlük bakım ürünü önerisinde bulunulmasında ve dermatopatolojik durumların saptanmasında menstrüel siklusun hangi döneminde olduğunun sonucu değiştirmeyeceğini göstermektedir. Yapılacak daha ayrıntılı ve uzun dönem çalışmalarla daha net sonuçlar elde edilebilir.

Anahtar Kelimeler: Deri, sebum, nem, pH

\section{Introduction}

Genetic and hormonal differences cause age-varying differences between the male and female sex on the structure and function of the skin. Structural and anatomical features, biochemical features, mechanical features, functional differences, responses to external stimuli, capillary structure, perception capabilities, skin color, hormonal effect, hair-sebaceous gland units differ between genders ${ }^{1-4}$.

Just as hormones play a role in the development of the skin, the skin itself has the ability to produce and secrete hormones as an endocrine organ ${ }^{5}$. Insulin-like growth factors, binding proteins, proopiomelanacortin derivatives, catecholamines, steroid hormones, vitamin $\mathrm{D}$, retinoids and eiazonoids are produced from the skin ${ }^{1}$. Hormones show their effects on the skin by binding to their receptors. However, the skin has the ability to metabolize hormones and convert them into active or inactive form. Hormones perform most of their biological activities on the skin ${ }^{6}$. Hormonal factors such as thyroid hormones, growth hormones, insulinlike growth factor, steroidogenesis, vitamin D metabolism have been shown to cause changes in the skin's structure ${ }^{5,7,8}$. However, another group of hormones that have not been studied as much as these endocrine parameters are hormones that play a role in the menstrual cycle.

Some physiological effects of estrogen and progesterone from cyclic changes in the menstrual cycle are observed in women of childbearing age. These cyclic fluctuations at the estrogen and progesterone levels affect many medical conditions, as in dermatological diseases. Many diseases such as asthma, migraine, epilepsy, diabetes, porphyria, catamenial (related menstrual bleeding) pneumothorax, acute appendicitis, myasthenia gravis and allergic rhinitis are affected by changes in estrogen and progesterone levels ${ }^{9}$.

Many dermatological diseases such as acne vulgaris, systemic lupus erythematosus and rosacea are affected by cyclic changes of estrogen and progesterone ${ }^{9}$.

Based on the studies, this study was planned considering that hormonal changes in the menstrual cycle may cause changes in the moisture, sebum and $\mathrm{pH}$ values of the skin. In this study, possible changes in the moisture, sebum and $\mathrm{pH}$ of the skin with the menstrual cycle were investigated. Thus, it is aimed to understand whether the hormonal changes that direct the menstrual cycle have observable effects on the skin. The data to be obtained by investigating the possible relationship of skin functionality with the menstrual cycle can contribute to the evaluation of normal skin and the development of recommendations for skin care, as well as the timing of the examinations to be performed in the investigation of various pathological conditions and the creation of a dermatological treatment approach.

In this study, possible changes in the moisture, sebum and $\mathrm{pH}$ of the skin with the menstrual cycle were investigated. Thus, it is aimed to understand whether the hormonal changes that direct the menstrual cycle have observable effects on the skin. The data to be obtained by investigating the possible relationship of skin functionality with the menstrual cycle can contribute to the evaluation of normal skin and the development of recommendations for skin care, as well as the timing of the examinations to be performed in the investigation of various pathological conditions and the creation of a dermatological treatment approach.

\section{Materials and Methods}

This study included 51 volunteer female patients, aged 21-45, who work at the medical faculty hospital, who have regular menstruation. Before starting the study, approval was obtained from the Ethics Committee of Adnan Menderes University Faculty of Medicine (approval number: 2011/013). Approval was received from the participants. The height and weight of the participants were measured. The body mass index (BMI) was calculated by dividing the weight by the square meter of the neck. A questionnaire consisting of 2 parts was made to the participants. In the first part of the questionnaire, the age, height, weight values, oral contraceptive use, smoking, alcohol use, skin care product use, systemic drug use were questioned. In the second part, the person's last menstrual history, whether there was an acne problem in adolescence and his/her skin structure were questioned.

The measurement was done with Courage \& Khazaka ${ }^{\circledR}$ MPA-5 device. The MPA-5 device consists of four different probes (corneometer, sebumeter, $\mathrm{pH}$ meter, mexameter), where the moisture, sebum, $\mathrm{pH}$, erythema and melanin levels of the skin can be measured and a computer associated with them. Moisture and $\mathrm{pH}$ measurements are completed by touching the probes for a few seconds to the area to be measured, and for sebum measurement by touching the relevant probe for 30 seconds, after seeing the desired data on the computer screen.

The properties of the probes (tips) used can be summarized as follows: Corneometer (CM 825): Determines the hydration on the skin through changes in electric current. One of its biggest advances is that it is minimal to be affected by the products applied to the skin. Since the measurement shows hydration occurring at a depth of 1020 micrometers, it is not affected by changes in the lower layers of the skin, for example, by bleeding. It only shows the hydration of the stratum corneum. To make a measurement, it is sufficient to touch the probe on the skin to be measured.

Sebumeter (SM 815): Measures according to the rules of photometry. Measurement is done with cassette-shaped probe. A transparent strip on the end of the cassette touches the skin surface. This cassette is then 
attached to the apparatus connected to the computer. The change in transparency according to the photocell rules is obtained as data by the computer program. An area of $64 \mathrm{~mm}^{2}$ is measured.

pH meter (pH905): It is used to evaluate the hydrolipid layer on the skin. It helps to detect changes with soap, cleaners and detergents. Measurement is made with a glass-tipped, flat bottom surface.

With MPA-5 device, skin type, sebum, pH changes of the skin, degree of hydration can be determined. It is a simple, easy-to-use device that can be used in diseases such as acne, rosacea, seborrheic dermatitis, melasma. The measurements made are non-invasive.

In this study, the facial skin $\mathrm{pH}$, moisture and sebum values of the participants were measured for 2 consecutive menstrual cycles, 6 times in total, at the beginning, middle and end of each cycle. Measurements for humidity and $\mathrm{pH}$, from 5 different points on the face (glabella, both cheeks zygomatic protrusions, over the mentum and nose in the chin); sebum measurement was made at $25{ }^{\circ} \mathrm{C}$ and $40-60 \%$ humidity, one measurement from glabella. $\mathrm{PH}$ and humidity values were determined by taking the average of five different regions. The values displayed on the computer screen were recorded manually at each measurement. Participants were advised not to use moisturizer on their face in the last 24 hours, wash their face with water only once on the day of measurement, and do not use cleaning products. The measurement was made in a room not under direct lamp or sunlight. Measurements were made at the same time of the day and in the same light conditions. The patient to be measured was rested for at least 10 minutes after the exercise to return the blood flow to normal. Since the probe's head attracts heat and prevents evaporation, at least 5 seconds was waited between the measurements since the stratum corneum could not be changed even though the water content of the stratum was changed. Pregnancy, menstrual irregularity, menopause, non-regular participation in measurements, any skin disease, inaccessibility due to workplace change were accepted as reasons for exclusion from the study. Individuals using any medication, having chronic or acute systemic disease, known to have hormonal disorders were excluded from the study.

The reference values that determine the skin type in MPA-5 device differ according to the regions of the face. The values found in the use of the MPA-5 device are indicated in the forehead, nose and chin region if the sebum value is less than 100, the skin type is oil-free, if it is between 100-220, it is normal and if it is over 220 fatty. Since we measured the sebum value from glabella in our study, we evaluated our results according to these references. For moisture values, $<30$ was considered very dry, 30-45 dry, $>45$ moist. For $\mathrm{pH}$, it was accepted as $<3.5$ acidic, $>6.5$ basic and 4.5-5.5 normal ${ }^{10}$.

\section{Statistical Analysis}

SPSS 14 program was used to evaluate the data. The suitability of quantitative data for normal distribution was examined with the Kolmogorov-Smirnov test. In the analysis of data suitable for normal distribution, t-test was used in dependent groups according to the group structure or t-test in independent groups, and descriptive statistics were shown in the form of mean - standard deviation. In the analysis of the data that are not suitable for normal distribution, Friedman test,
Mann-Whitney $U$ test or Wilcoxon test were used according to the group number and structure and the descriptive statistics were shown in the median (25-75 percentile) format. Correlation analysis was used to examine the relationships between quantitative variables. $\mathrm{P}<0.05$ value was accepted for statistical significance.

\section{Results}

The study started with 55 participants. Four people were excluded for various reasons. The age of the participants varied between 21 and 45 . The average age was $31.45 \pm 6.33$

The responses given by the individuals participating in the study to the first part of the questionnaire are shown in Table 1.

$14(27.5 \%)$ of the participants in the study were dry, $22(43.1 \%)$ were oily, 1 (2\%) were sensitive, 5 (9.8\%) were mixed, 9'u (17.6\%) thought it was normal. 39 (76.5\%) of the participants stated that they washed their face with water in the morning, $8(15.7 \%)$ with soap and $4(7.8 \%)$ with a cleaning cosmetic product.

Results of the measurements of 51 individuals participating in the study in the early follicular ( $3^{\text {rd }}$ day \pm 2 days), late follicular $\left(12^{\text {th }}\right.$ day \pm 2 days) and midluteal (20 th day \pm 3 days) phases of the menstrual cycle, Table 2 is also shown. There was no statistically significant difference

Table 1. Sociodemographic characteristics of the participants

\begin{tabular}{|l|l|l|}
\hline & $+\mathbf{( \% )}$ & $\mathbf{- ( \% )}$ \\
\hline Child & $29(56.9 \%)$ & $22(43.1 \%)$ \\
\hline Active sex life & $34(66.7 \%)$ & $17(33.3 \%)$ \\
\hline Oral contraceptive use & $2(3.9 \%)$ & $49(96.1 \%)$ \\
\hline Smoking & $14(27.5 \%)$ & $37(72.5 \%)$ \\
\hline Alcohol use & $3(5.9 \%)$ & $48(94.1 \%)$ \\
\hline Use of skin care products & $19(37.3 \%)$ & $32(62.7 \%)$ \\
\hline Systemic drug use & $6(11.8 \%)$ & $45(88.2 \%)$ \\
\hline $\begin{array}{l}\text { Acne history in } \\
\text { adolescence }\end{array}$ & $\begin{array}{l}22(43.1 \%) \\
\text { Comedonal: 6 }(11.8 \%) \\
\text { Papulopustular: 16 (31.4\%) }\end{array}$ & $29(56.9 \%)$ \\
\hline
\end{tabular}

Table 2. Sebum, moisture, pH values determined according to the menstrual cyclus phases

\begin{tabular}{|l|l|l|l|l|}
\hline & First (e) & Mid $(\mathbf{l})$ & End $(\mathbf{m})$ & $\mathbf{p}$ \\
\hline Sebum (1) & 197 & 176 & 194 & 0.755 \\
$(128.75-239.75)$ & $(135.25-233.75)$ & $(129.00-258.25)$ & \\
\hline Sebum (2) & 182 & $\begin{array}{l}206 \\
(103.75-256.75)\end{array}$ & $\begin{array}{l}208 \\
(140-271.75)\end{array}$ & 0.394 \\
\hline pH (1) & $\begin{array}{l}5.36 \\
(5.12-5.66)\end{array}$ & $\begin{array}{l}5.48 \\
(5.29-5.70)\end{array}$ & $\begin{array}{l}5.49 \\
(5.29-5.80)\end{array}$ & 0.352 \\
\hline pH (2) & $\begin{array}{l}5.51 \\
(5.18-5.87)\end{array}$ & $\begin{array}{l}5.53 \\
(5.28-5.87)\end{array}$ & $\begin{array}{l}5.54 \\
(5.24-5.81)\end{array}$ & 0.755 \\
\hline Moisture (1) & $\begin{array}{l}47.86 \\
(39.35-54.72)\end{array}$ & $\begin{array}{l}44.40 \\
(40.70-50.85)\end{array}$ & $\begin{array}{l}51.00 \\
(42.43-56.62)\end{array}$ & 0.066 \\
\hline Moisture (2) & $\begin{array}{l}48.10 \\
(39.55-54.92)\end{array}$ & $\begin{array}{l}46.70 \\
(38.58-52.76)\end{array}$ & $\begin{array}{l}47.60 \\
(40.49-51.41)\end{array}$ & 0.911 \\
\hline
\end{tabular}

*Friedman test is used in this table. 1: First menstrual cycle, 2: Second menstrual cycle, e: Early follicular phase, I: Late follicular phase, m: Midluteal phase 
between the moisture, sebum and $\mathrm{pH}$ values in the early follicular, late follicular and midluteal phases of the menstrual cycle for each month of measurement ( $p>0.05)$.

In-phase measurements of two menstrual cycles did not differ significantly. The consistency of our measurements with the MPA-5 device in two consecutive menstrual cycles is presented in Table 3.

In the first and second months, a statistically significant relationship was not found between the mean of the moisture, sebum and $\mathrm{pH}$ values measured 6 times, and the BMI and age (Table 4).

There was no significant relationship between smoking and mean humidity, sebum and $\mathrm{pH}$ values (Table 5). Since the number of people using alcohol was insufficient, no comparison was made between the groups.

In the measurements made with MPA-5, 35.3\% of the participants had dry skin, $64.7 \%$ of them were moist; it was determined that $2 \%$ of the

Table 3. Consistency of early follicular, late follicular and midluteal measurements in cycles

\begin{tabular}{|l|l|l|l|} 
& First cycle & Second cycle & $p$ \\
\hline Sebum $(\mathrm{e})$ & $204.04 \pm 99.87$ & $198.45 \pm 110.18$ & 0.749 \\
\hline Sebum $(\mathrm{I})$ & $200.83 \pm 111.74$ & $217.53 \pm 98.33$ & 0.238 \\
\hline Sebum $(\mathrm{m})$ & $209.29 \pm 100.95$ & $224.06 \pm 118.69$ & 0.434 \\
\hline $\mathrm{pH}(\mathrm{e})$ & $5.43 \pm 0.60$ & $5.48 \pm 0.57$ & 0.711 \\
\hline $\mathrm{pH}(\mathrm{I})$ & $5.50 \pm 0.44$ & $5.56 \pm 0.39$ & 0.455 \\
\hline $\mathrm{pH}(\mathrm{m})$ & $5.48 \pm 0.49$ & $5.55 \pm 0.40$ & 0.403 \\
\hline Moisture $(\mathrm{e})^{\star *}$ & $47.86(39.35-54.72)$ & $48.10(39.55-54.92)$ & 0.423 \\
\hline Moisture $(\mathrm{I})$ & $47.03 \pm 11.89$ & $46.74 \pm 11.27$ & 0.882 \\
\hline Moisture $(\mathrm{m})$ & $50.33 \pm 11.81$ & $47.81 \pm 11.81$ & 0.158 \\
\hline$*$ this tale & & &
\end{tabular}

${ }^{*}$ In this table, t-test and Wilcoxon test $\left({ }^{* *}\right)$ were used in dependent groups. First cycle: Values measured in the first menstrual cycle, Second cycle: Values measured in the second menstrual cycle, e: Early follicular phase, l: Late follicular phase m: Midluteal phase

Table 4. Relationship between body mass index and age and mean sebum, moisture and $\mathrm{pH}$ values

\begin{tabular}{|l|l|l|l|l|}
\hline \multirow{2}{*}{} & \multicolumn{2}{|l|}{ BMI } & \multicolumn{2}{l|}{ Age } \\
\cline { 2 - 5 } & r & p & r & p \\
\hline Sebum & 0.155 & 0.278 & 0.145 & 0.311 \\
\hline $\mathrm{pH}$ & 0.030 & 0.833 & 0.045 & 0.754 \\
\hline Moisture & 0.141 & 0.325 & 0.114 & 0.426 \\
\hline $\begin{array}{l}\text { *Correlation analysis is used in this table. } \\
\text { r: Correlation coefficient, p: Possibility, BMI: Body mass index }\end{array}$ \\
\hline
\end{tabular}

Table 5. Comparison between smoking and average moisture, sebum and $\mathrm{pH}$ values

\begin{tabular}{|l|l|l|l|}
\hline \multirow{2}{*}{} & \multicolumn{3}{|l|}{ Smoking } \\
\cline { 2 - 4 } & $\mathbf{( + )}$ & $\mathbf{( - )}$ & $\mathbf{p}$ \\
\hline Sebum & $230.85 \pm 60.50$ & $200.78 \pm 62.24$ & 0.127 \\
\hline $\mathrm{pH}$ & $5.39 \pm 0.23$ & $5.54 \pm 0.23$ & 0.400 \\
\hline Moisture & $49.37 \pm 10.92$ & $47.59 \pm 7.33$ & 0.503 \\
\hline * In this table, t-test was used in dependent groups \\
\hline
\end{tabular}

sebum value was low, $56.9 \%$ of them were normal and $41.2 \%$ of them were high. The $\mathrm{pH}$ value was found within normal limits at $47.1 \%$. For the moisture value <30: very dry, 30-45: dry, >45: moist; <100: oilfree, 100-220: normal, >220: oily for sebum value; these values were obtained by accepting <3.5: acidic, 4.5-5.5: normal, >6.5: basic values for the $\mathrm{pH}$ value. With the average humidity, sebum and $\mathrm{pH}$ values obtained in the measurements, There was no correlation between the thoughts of people about their own skin (Table 6).

While 29 people who participated in the study did not define acne history in adolescence, 22 people had a history of acne in adolescence. There was no correlation between the average moisture, sebum and $\mathrm{pH}$ values obtained in the measurements and whether there was a history of acne in adolescence (Table 7).

No relationship was found between acne history and sebum levels measured in different phases of the menstrual cycle (Table 8).

Table 6. The relationship between the person's foresight about the skin type and the average moisture, sebum and $\mathrm{pH}$ values determined with the MPA5 device

\begin{tabular}{|l|l|l|l|}
\hline \multirow{2}{*}{} & \multicolumn{3}{|l|}{ Skin type } \\
\cline { 2 - 4 } & Dry & Seborheic & p \\
\hline Sebum & $200.76 \pm 75.94$ & $223.36 \pm 65.02$ & 0.348 \\
\hline Moisture & $49.43 \pm 11.88$ & $47.16 \pm 7.42$ & 0.484 \\
\hline pH & $5.42 \pm 0.24$ & $5.53 \pm 0.24$ & 0.182 \\
\hline *In this table, t-test was used in independent groups \\
\hline
\end{tabular}

Table 7. The relationship between average moisture, sebum and $\mathrm{pH}$ values and adolescent acne history

\begin{tabular}{|l|l|l|l|}
\hline \multicolumn{4}{|l|}{ Acne history } \\
\cline { 2 - 4 } & $(+)$ & $(-)$ & p \\
\hline Sebum & $196.48 \pm 69.09$ & $218.56 \pm 56.66$ & 0.216 \\
\hline Moisture & $47.15 \pm 6.38$ & $48.78 \pm 9.69$ & 0.436 \\
\hline $\mathrm{pH}$ & $5.53 \pm 0.23$ & $5.48 \pm 0.24$ & 0.497 \\
\hline * In this table, t-test is used & \\
\hline
\end{tabular}

Table 8. The relationship between sebum levels in the early follicular, late follicular and midluteal phases of the menstrual cycle and the problem of acne in adolescence

\begin{tabular}{|c|c|c|c|}
\hline & \multicolumn{3}{|l|}{ Acne history } \\
\hline & $(+)$ & $(-)$ & $\mathbf{p}$ \\
\hline Sebum (1e) & $206.77 \pm 88.45$ & $201.97 \pm 109.23$ & 0.246 \\
\hline Sebum (1I) & $170.68 \pm 106.92$ & $223.69 \pm 111.65$ & 0.085 \\
\hline Sebum (1m) & $205.64 \pm 87.04$ & $212.07 \pm 111.78$ & 0.970 \\
\hline Sebum (2e) & $196.73 \pm 109.40$ & $199.76 \pm 112.68$ & 0.924 \\
\hline Sebum (2I) & $192.91 \pm 91.72$ & $236.21 \pm 100.60$ & 0.120 \\
\hline Sebum (2m) & $206.14 \pm 118.19$ & $237.66 \pm 119.31$ & 0.353 \\
\hline
\end{tabular}




\section{Discussion}

To date, studies have been conducted to investigate the effects of many factors such as aging, environmental factors, gender, racial differences, obesity and hormones on the skin. Hormonal factors such as thyroid hormones, growth hormone, insulin-like growth factor, steroidogenesis, vitamin $\mathrm{D}$ metabolism have been shown to cause changes in the structure of the skin $5,7,8$. However, changes in the skin caused by hormones involved in the menstrual cycle have not been studied as much as other endocrine parameters.

Menstruation is regulated by the hormones estrogen and progesterone, which are produced from ovaries and cause changes in many tissues and organs in the body. It contains many estrogens and less progesterone receptors on the $\mathrm{skin}^{6,11}$. Cyclic changes in estrogen and progesterone levels cause various changes in lipid release, sebum production, skin thickness, oil storage, skin hydration, skin elasticity and collagen content.

Estrogens increase the water binding capacity of the stratum corneum and dermis. They achieve this by increasing the amount of acid mucopolysaccharides and hyaluronic acid in the dermis ${ }^{6}$. There are few studies to show the effect of menstrual cycle on skin hydration. In a study by Berardesca et al..$^{12}$, there was no statistically significant difference in hydration and surface water loss during the menstrual cycle. In our study, it could be expected that moisture values would increase in the late follicular phase where estrogen peaked. However, in our measurements, no change in moisture values was detected in different phases of menstrual cycles.

Changes in estrogen levels also cause changes in skin color, permanent microflora and UV sensitivity ${ }^{1,6,13}$. Microflora changes are expected to change skin pH. In our study, no change in skin pH was detected during the menstrual cycle.

In women of reproductive age, corneocytes are completely covered with lipids, but in postmenopausal women this integrity is impaired ${ }^{1417}$. The hormone replacement therapy used in menopause has been shown to increase the lipid content of corneocytes ${ }^{12}$. The size of corneocytes is also higher in women of reproductive age than postmenopausal women and men $^{18}$. During the menstrual cycle, how the skin surface lipid content changed was shown, and it was shown that the surface lipid content increased between 16-20 days of the cycle compared to other days ${ }^{19}$. In our study, there was no statistically significant difference in sebum values during the menstrual cycle.

Estrogen stimulates epidermal melanogenesis. The effects of estrogens on pigmentation were first noticed by changes in pregnant women. When ointments containing estrogen are applied to children, color darkening has been noticed in the perineum area, linea alba and nipples similar to pregnant women ${ }^{20}$.

It is known that vasomotor function and blood circulation are affected by sex hormones ${ }^{21,22}$. Vasodilation begins to increase in the follicular phase, peaking one week before menstruation ${ }^{6}$. Vasodilation depends on both estrogen and progesterone height. Peripheral vascular resistance is inversely proportional to estradiol levels. Studies evaluating the relationship between body temperature changes and menstrual cycle during rest and exercise have also been conducted. In a study, it was found that the basal body temperature was $0.3-0.5^{\circ} \mathrm{C}$ higher in the luteal phase than the follicular phase ${ }^{23}$. These changes in hormones and body temperature are in line with blood flow changes in the skin.
These changes in body temperature did not cause any changes in sebum, humidity and $\mathrm{pH}$ values in our study.

In a similar study conducted by Muizzuddin et al. ${ }^{19}$ in women aged 21-48, the menstrual cycle and skin barrier function, moisture values, lactic acid irritation response, surface lipids and surface microflora, minimal erythema response with ultraviolet, weekly, It was evaluated with repeated measurements for 2-3 months. The barrier function was the weakest between 22-26 days, irritation response to lactic acid did not change, the skin dryness was the most intense between 1-6 days of the menstrual cycle, the surface lipids were highest between 16-20 days, and the microflora was the most intense between 16-22 days. UV sensitivity was found to be highest between 20-28 days. These data can be interpreted that the moisture values in the skin are low in the early follicular phase, sebum values are high in the midluteal phase, and $\mathrm{pH}$ values are low in the late follicular phase. However, there was no difference in humidity, sebum and $\mathrm{pH}$ values measured in our study, which reached statistical significance in different phases of the menstrual cycle. Different results in our study with the research of Muizzuddin et al. ${ }^{19}$ may be due to some methodological differences such as weekly measurement, measurement according to the menstrual cycle period, direct $\mathrm{pH}$ measurement with evaluation of microflora.

\section{Study Limitations}

Although the study design does not have a significant limitation, the fact that the measurements are limited to a single cycle, considering that the menstrual cycle may differ slightly in the same individual, may prevent a clearer conclusion.

\section{Conclusion}

In the light of the studies carried out to date, it has been shown that changing hormone levels in the menstrual cycle cause changes in various structural components of the skin (stratum corneum thickness, surface lipid release, microflora structure, barrier function, thickness of collagen fibers, skin elasticity etc). However, it was observed that these structural changes did not change the moisture, sebum and $\mathrm{pH}$ values measured in our study.

In our study, in order to investigate the relationship between moisture, sebum and $\mathrm{pH}$ changes of healthy skin with the menstrual cycle, skin moisture, sebum and pH, with MPA-5 device, a total of 6 in 2 consecutive menstrual cycles in early follicular, late follicular (ovulation) and midluteal phase was measured times. In the measurements made, no statistically significant difference was found between the changing hormone levels in the menstrual cycle and the moisture, sebum and pH values of the skin.

Based on the data in these studies, we thought that hormonal changes in the menstrual cycle may cause changes in the skin's moisture, sebum and $\mathrm{pH}$ values. Contrary to the predictions, no changes were found in the moisture, sebum level and pH values of the skin in different phases of the menstrual cycle.

No similar study investigating the relationship of sebum, moisture and $\mathrm{pH}$ values with menstrual cycle, which has been done previously, has been encountered in the literature. In this respect, our study is a first in the literature and our data may be a guide for other studies in which the location of the menstrual cycle in skin physiology will be investigated. Our study was carried out with the MPA-5 device that provides reliable 
and objective data. Therefore, the data and results obtained are reliable. Since the measurements made on the participants are averaged over the different points of the face, the measured values reflect the overall values measured on the face. Also, the consistency of the values in the two menstrual cycles measured indicates the reliability of the device and the measurements. Since the majority of the group studied on are nurses working in our university, follow-up of reliability measurements and compliance with the suggestions can be followed regularly.

The female population between the ages of 20 and 40 was included in our study. In the light of the data shown by our study, a similar study can be made on different age groups from menarche to menopause, and the effects of age groups on humidity, sebum and $\mathrm{pH}$ values can be observed. Correlation of moisture, sebum and ph values with hormones can be evaluated more clearly by looking at the hormonal values in the blood simultaneously on the measured days. Measurements were made at 5 points on the face. Data obtained from different parts of the body by making more measurements can be enriched.

In our study, if hormonal changes in the menstrual cycle were found to change the moisture, sebum and $\mathrm{pH}$ values of the skin, women could be recommended to use different care products in different phases of the menstrual cycle. In order to detect changes in normal skin findings, we may have to consider what period of menstrual cycle we examined. It was conceivable to consider that the pathological conditions to be detected may have different appearances in different phases of the menstrual cycle. However, our data showed that it is not necessary to take into account the menstrual cycle in terms of timing in our female patients of childbearing age when recommending care products or creating the examination schedule.

The functioning of normal healthy skin must be understood before the skin pathologies can be treated. This makes it necessary to examine various parameters. Although there are studies in the literature examining the relationship between sebum and moisture values with the menstrual cycle, the results are far from being comprehensive and inclusive. For this reason, it is hoped that our study, which was carried out with measurements made through the MPA-5 device in 51 healthy volunteers, will contribute significantly to the literature.

\section{Ethics}

Ethics Committee Approval: Before starting the study, approval was obtained from the Ethics Committee of Adnan Menderes University Faculty of Medicine (approval number: 2011/013).

Informed Consent: Approval was received from the participants.

Peer-review: Externally peer-reviewed.

\section{Authorship Contributions}

Surgical and Medical Practices: N.K., E.Ş., Concept: N.K., E.Ş., Design: N.K., E.Ş., Data Collection or Processing: N.K., E.Ş., Analysis or Interpretation: N.K., E.Ş., M.U., N.Ş., G.K., Literature Search: N.K., E.Ş., S.D., Writing: N.K., E.Ş., S.D.

Conflict of Interest: No conflict of interest was declared by the authors.
Financial Disclosure: The authors declared that this study received no financial support.

\section{References}

1. Zouboulis CC, Chen WC, Thornton MJ, Qin K, Rosenfield R: Sexual hormones in human skin. Horm Metab Res 2007;39:85-95.

2. Alam H, Sehgal L, Kundu ST, Dalal SN, Vaidya MM: Novel function of keratins 5 and 14 in proliferation and differentiation of stratified epithelial cells. Mol Biol Cell 2011;22:4068-78.

3. Giacomoni PU, Mammone T, Teri M: Gender-linked differences in human skin. J Dermatol Sci 2009;55:144-9.

4. Seidenari S, Pagnoni A, Di Nardo A, Giannetti A: Echographic evaluation with image analysis of normal skin: variations according to age and sex. Skin Pharmacol 1994;7:201-9.

5. Zouboulis CC: The human skin as a hormone target and an endocrine gland. Hormones 2004;3:9-26.

6. Farage MA, Neill S, MacLean AB: Physiological changes associated with the menstrual cycle: a review. Obstet Gynecol Surv 2009;64:58-72.

7. Zouboulis CC: The skin as an endocrine organ. Dermatoendocrinol 2009;1:250-2.

8. Slominski A, Wortsman J, Paus R, Elias PM, Tobin DJ, Feingold KR: Skin as an endocrine organ: implications for its function. Drug Discov Today Dis Mech 2008;5:137-44.

9. Boggess $\mathrm{KA}$, Williamson $\mathrm{HO}$, Homm RJ: Influence of the menstrual cycle on systemic diseases. Obstet Gynecol Clin North Am 1990;17:321-42.

10. Information and operating instructions for the multi probe adapter (MPA) and its probes.

11. Thornton MJ: The biological actions of estrogens on skin. Exp Dermatol 2002;11:487-502.

12. Berardesca E, Gabba P, Farinelli N, Borroni G, Rabbiosi G: Skin extensibility time in women. Changes in relation to sex hormones.Acta DermVenereol 1989;69:431-3.

13. Hirobe T: How are proliferation and differentiation of melanocytes regulated? Pigment Cell Melanoma Res 2011;24:462-78.

14. Denda M, Koyama J, Hori J, et al: Age- and sex-dependent change in stratum corneum sphingolipids. Arch Dermatol Res 1993;285:415-7.

15. Jacobi U, Gautier J, Sterry W, Lademann J: Gender-related differences in the physiology of the stratum corneum. Dermatology 2005;211:312-7.

16. Koçer M, Guldur T, Akarcay M, Miman MC, Beker G: Investigation of age, sex and menstrual stage variation in human cerumen lipid composition by high performance thin layer chromatography. J LaryngolOtol 2008;122:881-6.

17. Zouboulis CC, Boschnakow A: Chronological ageing and photoageing of the human sebaceous gland. Clin Exp Dermatol 2001;26:600-7.

18. Misra M, Feinberg C, Matzke M, Pocalyko D: Effect of hormone replacement therapy on epidermal barrier lipids. Int J Cosmet Sci 2005;28:335-42.

19. Muizzuddin N, Marenus KD, Schnittger SF, Sullivan M, Maes DH: Effect of systemic hormonal cyclicity on skin. J Cosmet Sci 2005;56:311-21.

20. Thornton MJ: The biological actions of estrogens on skin. Exp Dermatol 2002;11:487-502.

21. Duckles SP, Krause DN, Miller VM: Effects of gonadal steroids on vascular function. J Pharmacol Exp Ther 1996;279:1-3.

22. Fulton CT, Stallone JN: Sexual dimorphism in prostanoid-potentiated vascular contraction: roles of endothelium and ovarian steroids. Am J Physiol Heart Circ Physiol 2002;283:2062-73.

23. Hessemer V, Brück K: Influence of menstrual cycle on shivering, skin blood flow, and sweating responses measured at night. J Appl Physiol 1985;59:1902-10. 